\title{
Glosa do Wyroku Naczelnego Sądu Administracyjnego Z DNIA 20 GRUDNIA 2018 R., II OSK 249/17, LEX NR 2616392
}

Jeżeli inwestor po dokonaniu istotnych odstępstw od zatwierdzonego projektu budowlanego i warunków ostatecznej decyzji o pozwoleniu na budowę utraci uprawnienie do wykonania decyzji nakazujacej doprowadzenie wykonanych robót do stanu zgodnego z prawem, to zgodnie z ustawowa kolejnością określania podmiotów zobowiązanych do usuwania skutków naruszeń prawa budowlanego, właściwe organy maja obowiązek obciążenia obowiazkiem wykonania nakazu aktualnego właściciela nieruchomości, na której posadowiony jest obiekt budowlany, w stosunku do którego wydano decyzję o pozwoleniu na wykonanie robót budowlanych.

Glosowany wyrok zapadł w związku z zagadnieniem odstępstwa od zatwierdzonego projektu budowlanego dotyczącego obowiązku sporządzenia i przedstawienia projektu budowlanego zamiennego przez inwestora w celu doprowadzenia robót do stanu zgodnego z prawem.

W stanie faktycznym, leżącym u podstaw komentowanego orzeczenia NSA, w październiku 1999 r. Prezydent miasta Krakowa wydał decyzję o pozwoleniu na budowę dla inwestycji polegającej na przebudowie i adaptacji poddasza na cele mieszkalne wraz z wewnętrznymi instalacjami: wodno-kanalizacyjną, elektryczną i gazową. Inwestorzy przystąpili do realizacji robót budowlanych. Jednak w trakcie tego przedsięwzięcia doszło do odstępstwa od zatwierdzonego projektu budowlanego i warunków

* Dr, Wyższa Szkoła Administracji w Bielsku-Białej, Filia w Stalowej Woli; e-mail: zwolak@poczta.fm, https:/ / orcid.org/0000-0002-4075-4400. 
pozwolenia na budowę. Inwestorzy sprzedali następnie udziały w nieruchomości na rzecz osób trzecich. W związku z odstępstwami od zatwierdzonego projektu budowlanego Powiatowy Inspektor Nadzoru Budowlanego (PINB) nałożył na współwłaścicieli nieruchomości obowiązek przedstawienia $\mathrm{w}$ określonym $\mathrm{w}$ decyzji terminie czterech egzemplarzy projektu budowlanego zamiennego dla wspomnianej inwestycji. Jak wskazał PINB, w sytuacji gdy doszło do odstępstwa od zatwierdzonego projektu budowlanego, zgodnie z art. 51 ust. 1 pkt 3 ustawy z dnia 7 lipca 1994 r. - Prawo budowlane ${ }^{1} \mathrm{w}$ zw. $\mathrm{z}$ art. 51 ust. 7 tej ustawy organ nadzoru budowlanego jest zobowiązany do nałożenia obowiązku sporządzenia i przedstawienia projektu budowlanego zamiennego, uwzględniającego zmiany wynikające $\mathrm{z}$ dotychczas wykonanych robót budowlanych, oraz określenia terminu realizacji tego obowiązku. Podmioty zobowiązane do wykonania tego obowiązku zostały wskazane w art. 52 Prawa budowlanego. Zgodnie z tym przepisem inwestor, właściciel lub zarządca obiektu budowlanego jest obowiązany dokonać na swój koszt czynności nakazanych w decyzji, o której mowa w art. 48, art. 49b, art. 50a oraz art. 51 Prawa budowlanego. Zdaniem PINB obowiązek przedłożenia projektu budowlanego zamiennego należy w przedmiotowej sytuacji nałożyć na współwłaścicieli nieruchomości, a nie na inwestorów. Od tej decyzji współwłaściciele nieruchomości złożyli odwołanie. Jednak organ odwoławczy - Wojewódzki Inspektor Nadzoru Budowlanego (WINB) - utrzymał decyzję PINB w mocy.

Od decyzji WINB jeden ze współwłaścicieli nieruchomości złożył skargę do WSA w Krakowie, którą ten jednak oddalił, podzielając stanowisko organów administracji. Zdaniem WSA w niniejszej sprawie obowiązek sporządzenia zamiennego projektu budowlanego powinien być nałożony na współwłaścicieli nieruchomości. Inwestorzy sprzedali bowiem nieruchomość i obecnie nie dysponują do niej tytułem prawnym, który umożliwiłby wykonanie nakazu sporządzenia i przedstawienia projektu zamiennego. Od wyroku WSA jeden ze współwłaścicieli nieruchomości złożył skargę kasacyjną do NSA. Podniósł w niej, że w przedmiotowej sprawie postępowanie przed organami administracyjnymi toczyło się przez kilkanaście lat. $W$ tym czasie inwestorzy, mając świadomość niezgodności inwestycji z prawem, zbyli udziały w nieruchomości na rzecz obecnych współwłaścicieli. Skarżący kasacyjnie podkreślił, że przy zakupie owej nieruchomości nie został poinformowany o niezgodności z prawem

1 Dz. U. z 2020 r. poz. 1333 (dalej: Prawo budowlane). 
budowlanym, a wręcz zapewniono go o braku wad prawnych wyodrębnionego lokalu. Gdy w świetle prawa dochodzi do sprzedaży przez inwestorów udziału w nieruchomości, na której inwestor wykonał roboty budowlane z przekroczeniem zatwierdzonego projektu budowlanego, za które to odstępstwo inwestor nie ponosi żadnej odpowiedzialności, podczas gdy spada ona na współwłaścicieli nieruchomości, to zdaniem skarżącego stoi to $\mathrm{w}$ sprzeczności zarówno $\mathrm{z}$ interesem społecznym, jak i interesem jednostkowym obecnych współwłaścicieli nieruchomości. NSA nie podzielił jednak argumentów skarżącego i oddalił skargę kasacyjną. Sąd podkreślił, że w niniejszej sprawie dla ustalenia podmiotu, na który należy nałożyć obowiązek przedłożenia zamiennego projektu budowlanego, należy sięgnąć do art. 52 Prawa budowlanego. Przepis ten wymienia te podmioty w ściśle określonej kolejności. Są nimi: inwestor, właściciel lub zarządca obiektu budowlanego. W pierwszej kolejności zobowiązany do dokonania czynności jest zatem inwestor, chyba że w okolicznościach sprawy podmiot ten $\mathrm{w}$ dacie orzekania już nie istnieje bądź nie ma tytułu do nieruchomości lub obiektu, który upoważniałby do wykonania czynności nakazanych decyzją. Taka sytuacja ma miejsce, gdy inwestor zbył nieruchomość, której dotyczy przedmiot postępowania, na rzecz innych osób. Analogiczna sytuacja miała miejsce w przedmiotowej sprawie. Inwestorzy nie mają obecnie tytułu prawnego do dysponowania nieruchomością, zatem nałożenie na nich obowiązku przedstawienia projektu zamiennego (a w dalszej kolejności ewentualnie wykonania innych czynności) mogłoby okazać się niewykonalne. Tym samym wspomniany obowiązek powinien obciążać współwłaścicieli nieruchomości.

Dla potrzeb analizy przedmiotowego wyroku NSA na wstępie należy wyjaśnić podstawowe kwestie będące przedmiotem niniejszego orzeczenia. W prawie budowlanym instytucja zatwierdzonego przez właściwy organ administracji publicznej projektu budowlanego jest wyrazem bieżących potrzeb inwestora, co ma eliminować powstanie ewentualnych przeszkód na drodze do realizacji inwestycji ${ }^{2}$. Inwestor, chcąc dokonać zmiany, powinien zadbać $\mathrm{w}$ pierwszej kolejności o zsynchronizowanie planowanych czynności z etapem procesu budowlanego, na jakim

2 Zatwierdzony projekt budowlany stanowi istotny element postępowania w sprawie wydania pozwolenia na budowę. Zazwyczaj wydawany jest w samej decyzji o pozwoleniu na budowę, wyjątkowo zaś w decyzji odrębnej, Z. Leoński, M. Szewczyk, Podstawowe instytucje planowania przestrzennego i prawa budowlanego, Poznań 1997, s. 157. 
znajduje się inwestycja, oraz charakterem zamierzonych zmian. Gdy proces budowlany jest $\mathrm{w}$ toku, perspektywa wprowadzenia korekt do zatwierdzonego projektu budowlanego poprzez zmianę pozwolenia na budowę lub bez takiej zmiany pozostaje dla inwestora otwarta.

Wymóg uzyskania decyzji o zmianie pozwolenia na budowę z art. 36a Prawa budowlanego zależy od spełnienia przesłanki o charakterze wartościującym ${ }^{3}$. Zmianę pozwolenia na budowę na podstawie art. 36a Prawa budowlanego przeprowadza się jedynie $\mathrm{w}$ razie istotnego odstępstwa od zatwierdzonego projektu budowlanego lub innych warunków pozwolenia na budowę ${ }^{4}$. W stanie faktycznym niniejszego wyroku, który dotyczył wcześniejszego stanu prawnego, istotne odstąpienie zostało wyrażone na podstawie art. 36a ust. 5 Prawa budowlanego poprzez wskazanie, że nieistotne odstąpienia w omawianym zakresie nie wymagają uzyskania decyzji o zmianie pozwolenia na budowę i są dopuszczalne ${ }^{5}$, o ile nie dotyczą:

1) zakresu objętej projektem zagospodarowania działki lub terenu;

2) charakterystycznych parametrów obiektu budowlanego: kubatury, powierzchni zabudowy, wysokości, długości, szerokości i liczby kondygnacji;

3) zapewnienia warunków niezbędnych do korzystania z tego obiektu przez osoby niepełnosprawne;

4) zmiany zamierzonego sposobu użytkowania obiektu budowlanego lub jego części;

5) ustaleń miejscowego planu zagospodarowania przestrzennego lub decyzji o warunkach zabudowy i zagospodarowania terenu;

3 Z. Cieślik, Komentarz do zmiany art. 36(a) ustawy - Prawo budowlane wprowadzonej przez Dz. U. z 2003 r. Nr 80 poz. 718, 2003 [wyd. el. LEX].

4 Zob. E. Radziszewski, Prawo budowlane. Przepisy i komentarz, Warszawa 2005, s. 111. Istotne odstąpienie $\mathrm{w}$ rozumieniu art. 36a ust. 1 Prawa budowlanego nie może oznaczać wybudowania innego obiektu, choćby jego przeznaczenie było podobne czy nawet identyczne. Ponieważ decyzja o pozwoleniu na budowę dotyczy ściśle określonego obiektu budowlanego, to również odstępstwa mogą dotyczyć tylko obiektu określonego w tejże decyzji, A. Fronczak, Postępowanie w sprawie istotnego odstapienia od zatwierdzonego projektu budowlanego lub innych warunków pozwolenia na budowe, Kwartalnik Prawa Publicznego 2013, t. 13, nr 3, s. 7.

Za nieistotne odstępstwa w rozumieniu art. 36a Prawa budowlanego przyjmuje się takie, które nie powodują naruszenia przepisów prawa budowlanego i nie wpłynęłyby na treść decyzji o pozwoleniu na budowę czy zatwierdzeniu projektu budowlanego. Inaczej ujmując, inwestor uzyskałby pozwolenie na budowę obiektu ukształtowanego przez dokonane zmiany, zob. wyrok NSA z dnia 20 marca 2001 r., SA/Bk 1521/00, LEX nr 657438. 
6) nie wymagają uzyskania opinii, uzgodnień, pozwoleń i innych dokumentów wymaganych przepisami szczególnymi.

Z powyższego wynika, że legislator, określając katalog istotnych odstępstw, posłużył się wówczas techniką ich negatywnego zdefiniowania ${ }^{6}$. Mając jednak na uwadze, że kwalifikacje zmian do projektu budowlanego wzbudzały od lat wiele wątpliwości w orzecznictwie sądowo-administracyjnym, ustawodawca wprowadził nowe uregulowanie art. 36a Prawa budowlanego, stwierdzając, że istotne odstąpienie od zatwierdzonego projektu budowlanego lub innych warunków pozwolenia na budowę stanowi odstąpienie w zakresie:

1) projektu zagospodarowania działki lub terenu, z wyjątkiem urządzeń budowlanych oraz obiektów małej architektury;

2) charakterystycznych parametrów obiektu budowlanego: kubatury, powierzchni zabudowy, wysokości, długości, szerokości i liczby kondygnacji obiektu budowlanego, z zastrzeżeniem wskazanych warunków, które nie są istotnym odstąpieniem od zatwierdzonego projektu;

3) zapewnienia warunków niezbędnych do korzystania z obiektu budowlanego przez osoby niepełnosprawne, o których mowa w art. 1 Konwencji o prawach osób niepełnosprawnych, sporządzonej w Nowym Jorku dnia 13 grudnia 2006 r., w tym osoby starsze;

4) zmiany zamierzonego sposobu użytkowania obiektu budowlanego lub jego części;

5) ustaleń miejscowego planu zagospodarowania przestrzennego, innych aktów prawa miejscowego lub decyzji o warunkach zabudowy i zagospodarowania terenu; wymagającym uzyskania lub zmiany uzgodnień lub pozwoleń, które są konieczne do uzyskania pozwolenia na budowę lub dokonania zgłoszenia: budowy, o której mowa w art. 29 ust. 1 pkt 1a, 2b i 19a Prawa budowlanego lub przebudowy, o której wspomina art. 29 ust. 2 pkt 1b Prawa budowlanego.

Nie jest jednak istotnym odstąpieniem od zatwierdzonego projektu budowlanego lub innych warunków pozwolenia na budowę zmiana wysokości, szerokości lub długości obiektu budowlanego niebędącego obiektem liniowym, jeżeli odstąpienie łącznie spełnia następujące warunki:

6 A. Kosicki, Komentarz do art. 36a pr. bud., w: Prawo budowlane. Komentarz, red. A. Plucińska-Filipowicz, M. Wierzbowski, 2015 [wyd. el. LEX] i przywołany tam wyrok NSA z dnia 6 czerwca 2008 r., II OSK 461/07, LEX nr 486488. 
1) nie przekracza $2 \%$ wysokości, szerokości lub długości obiektu budowlanego określonych w projekcie budowlanym;

2) nie zwiększa obszaru oddziaływania obiektu;

3) nie mieści się w zakresie odstępstw, o których mowa w art. 36a ust. 5 pkt 3-6 Prawa budowlanego, z wyjątkiem odstępstwa od projektowanych warunków ochrony przeciwpożarowej, jeżeli odstępstwo zostało uzgodnione z rzeczoznawcą do spraw zabezpieczeń przeciwpożarowych;

4) nie narusza przepisów techniczno-budowlanych.

Podstawą do ingerencji organów nadzoru budowlanego w trybie art. 51 ust. 1 pkt $3 \mathrm{w}$ zw. z art. 36a Prawa budowlanego jest bezsporne ustalenie, że inwestor zrealizował lub realizuje obiekt budowlany $\mathrm{z}$ istotnymi odstępstwami od zatwierdzonego projektu budowlanego. W orzecznictwie sądowo-administracyjnym pojawia się pogląd głoszący, że o tym, czy projektowana modyfikacja będzie miała istotny charakter, decyduje całokształt okoliczności konkretnego przypadku. Odstąpienie od zatwierdzonego projektu budowlanego może zatem w poszczególnych sprawach zostać ocenione $\mathrm{w}$ odmienny sposób w zależności m.in. od charakteru obiektu budowlanego i jego rozmiarów ${ }^{7}$. O tym, czy określone odstępstwo od projektu budowlanego okazuje się istotne, decyduje projektant, który ma obowiązek zamieścić w projekcie stosowne informacje dotyczące odstępstwa ${ }^{8}$. Jednakże praktyka wskazuje, że często występują sytuacje, gdy dokonywanie kwalifikacji odstąpienia jako istotne lub nie następuje poprzez odpowiedzi na pytania zadawane przez projektantów bądź inwestorów udzielane przez PINB. Jednak w świetle art. 36a ust. 6 Prawa budowlanego praktyka taka nie znajduje uzasadnienia w przepisach, choć może stanowić korzystny instrument ochronny dla projektantów i inwestorów. Ustawodawca $\mathrm{w}$ art. 36a ust. 6 Prawa budowlanego wyraźnie przyznaje projektantowi kompetencje do kwalifikowania odstępstw w projekcie budowlanym. Przepis ten wprost potwierdza uprawnienie projektanta do klasyfikacji zmian w związku z faktem, że to przede wszystkim on jako

7 Wyrok WSA w Gliwicach z dnia 8 maja 2014 r., II SA/GL 1883/13, LEX nr 1465352.

8 Należy zauważyć, że kompetencja projektanta do dokonywania kwalifikacji zamierzonego odstąpienia od zatwierdzonego projektu budowlanego jest negatywnie oceniana w doktrynie prawa. W dyskusjach podnosi się kwestię, że kompetencja ta nie powinna być powierzana projektantowi, który pozostaje związany z inwestorem, ale organowi administracji publicznej, J. Dessoulavy-Śliwiński, Komentarz do art. 36a pr. bud., w: Prawo budowlane. Komentarz, red. Z. Niewiadomski, Warszawa 2018, s. 437. 
autor projektu powinien dokonywać swoistej interpretacji sporządzonego przez siebie projektu i oceniać zakres dokonywanych w nim modyfikacji. Z kolei organom administracji publicznej można przypisać jedynie rolę kontrolną na etapie zatwierdzania zamiennego projektu budowlanego po jego weryfikacji. Prowadzi to w rzeczywistości do rezultatu, który nie był zamierzony przez ustawodawcę przy projektowaniu art. 36a ust. 6 Prawa budowlanego. Okazuje się bowiem, że to właściwy organ administracji publicznej rozstrzyga o stopniu odstępstwa od pozwolenia na budowę na zasadzie swobodnego uznania, które należy szczegółowo umotywować9. Cecha ta powinna znajdować uzasadnienie w dodatkowych jeszcze okolicznościach, rzutujących na charakter stwierdzonej modyfikacji ${ }^{10}$.

Postępowanie $\mathrm{w}$ sprawie zmiany pozwolenia na budowę nie ma na celu sanowania samowoli budowlanej, za jaką należy uznać wszelkie istotne odstępstwa niepoprzedzone uzyskaniem pozwolenia na budowę ${ }^{11}$. Pozwolenie zamienne, które musi być uzyskane przed realizacją zmian, jest bowiem instytucją prawną. Jeżeli inwestor wie, że chce wprowadzić istotne modyfikacje, powinien wystąpić o pozwolenie zamienne i jednocześnie tak zaplanować roboty, aby przed jego uzyskaniem móc ewentualnie realizować ich inną część, objętą dotychczasowym pozwoleniem (nieulegającą zmianom) ${ }^{12}$. W celu zmiany pozwolenia na budowę inwestor składa odpowiedni wniosek wraz z wymaganymi dokumentami do właściwego organu administracji publicznej, który wydał pozwolenie na budowę ${ }^{13}$. Możliwość dokonania zmiany w realizowanym już pozwoleniu na budowę jest prewencyjnym środkiem przeciwdziałania łamaniu

9 Wyrok WSA w Warszawie z dnia 12 maja 2011 r., VII SA/Wa 2071/10, LEX nr 1133266.

10 M. Bielecki, Proces inwestycyjno-budowlany - aspekty prawne, Warszawa 2016, s. 214.

11 Wyrok NSA z dnia 8 grudnia 2006 r., II OSK 44/06, LEX nr 507162.

12 Ł. Bernatowicz, M. Nosiński, Prawo budowlane od dnia 28 czerwca 2015 r. Szczegótowy komentarz do zmian, Gdańsk 2015, s. 77.

13 Wniosek o wydanie nowego pozwolenia na budowę stanowi oświadczenie woli inwestora skierowane do właściwego organu administracji publicznej. Należy do zbiorczej kategorii podań w rozumieniu art. 63 Kodeksu postępowania administracyjnego (ustawa z dnia 14 czerwca 1960 r. - Kodeks postępowania administracyjnego, Dz. U. z 2018 r. poz. 2096 z późn. zm.; dalej K.p.a.). Zgodnie z art. 63 § 1 K.p.a. podania (żądania, wyjaśnienia, odwołania, zażalenia) mogą być wnoszone pisemnie, telegraficznie, za pomocą telefaksu lub ustnie do protokołu, a także za pomocą innych środków komunikacji elektronicznej przez elektroniczną skrzynkę podawczą organu administracji publicznej. Warto zauważyć, że zdaniem A. Wróbla art. 63 § 1 K.p.a. nie określa wszystkich możliwych 
prawa $\mathrm{w}$ trakcie prowadzenia robót budowlanych ${ }^{14}$. Mając na uwadze, że w czasie procesu budowlanego mogą zaistnieć modyfikacje $\mathrm{w}$ danym obiekcie budowlanym, prawodawca wychodzi naprzeciw potrzebom uczestników procesu budowlanego, ustanawiając odpowiednie regulacje prawne w tym zakresie. Ustawodawca, dążąc do przeciwdziałania lub likwidacji skutków ewentualnej samowoli budowlanej, polegającej na istotnym odstąpieniu od zatwierdzonego projektu budowlanego lub innych warunków pozwolenia na budowę, wprowadza art. 36a Prawa budowlanego, który stanowi, że odstąpienie jest dopuszczalne jedynie po uzyskaniu decyzji o zmianie pozwolenia na budowę. Obowiązek uzyskania zamiennego pozwolenia na budowę ma zapobiegać możliwości istotnego odstąpienia lub likwidować jego skutki.

Z glosowanego wyroku NSA szczególnego znaczenia nabiera treść art. 52 Prawa budowlanego, z którego sąd wywiódł pogląd, że gdy doszło do odstępstwa od zatwierdzonego projektu budowlanego, nakaz doprowadzenia robót do stanu zgodnego z prawem należy nałożyć na inwestora. W sytuacji kiedy utracił on tytuł prawny do nieruchomości, nakaz należy skierować do właściciela.

W myśl art. 52 Prawa budowlanego inwestor, właściciel lub zarządca obiektu budowlanego jest obowiązany na swój koszt dokonać czynności nakazanych w decyzji, o której mowa w art. 48, art. 49b, art. 50a oraz art. 51 Prawa budowlanego. Wynika z tego, że przepis art. 52 Prawa budowlanego określa nie tylko osobę zobowiązaną do wykonania na swój koszt czynności nakazanych w decyzjach dotyczących rozbiórki obiektu budowlanego, lecz także obowiązek, który nakładany jest na osobę w drodze jednej z wymienionych decyzji. Według art. 52 Prawa budowlanego adresatem decyzji może być inwestor, właściciel bądź zarządca obiektu budowlanego. Ustawodawca, wskazując expressis verbis podmioty zobowiązane do dokonania określonych czynności w celu przywrócenia robót budowlanych do stanu zgodnego z prawem, nie uregulował jednocześnie w sposób czytelny przesłanek ustalenia adresata decyzji, gdy chodzi o wybór pomiędzy inwestorem, właścicielem lub zarządcą obiektu budowlanego. Wydaje się jednak, że kolejność wymienionych podmiotów

sposobów wniesienia podania do organu administracji publicznej, M. Jaśkowska, A. Wróbel, Kodeks postępowania administracyjnego. Komentarz, Kraków 2000, s. 432.

14 Zob. T.B. Babiel, Nadzór budowlany. Kompetencje organów administracji. Wzory. Akty prawne, Warszawa 2001, s. 64. 
nie pozostaje bez znaczenia. Jest ona istotna dla wyboru osoby zobowiązanej, choć trzeba zaznaczyć, że nie należy jej traktować jako jedyne kryterium. W orzecznictwie sądowo-administracyjnym nie budzi wątpliwości to, że z przepisu art. 52 Prawa budowlanego nie wynika dowolność organów administracji w wyborze podmiotu zobowiązanego do wykonania. Sądy administracyjne wyrażają trafny pogląd, zgodnie z którym w pierwszej kolejności zobowiązany do dokonania określonych czynności zostaje inwestor ${ }^{15}$. Zawsze jest nim podmiot, który złożył wniosek o wydanie pozwolenia na budowę, a następnie stał się adresatem wydanej $\mathrm{w}$ tym przedmiocie decyzji. Niewątpliwie uczestniczy on w procesie budowlanym. Choć samo pojęcie inwestora nie zostało wprost zdefiniowane w prawie budowlanym, to nie powinno nasuwać większych wątpliwości. Inwestorem jest osoba fizyczna lub prawna albo inna jednostka organizacyjna, która inicjuje podjęcie działalności budowlanej niezbędnej do realizacji zamierzonej inwestycji ${ }^{16}$.

W sytuacji kiedy inwestor już nie istnieje w dacie orzekania bądź nie ma tytułu do nieruchomości lub obiektu budowlanego, który upoważniałby do wykonania czynności nakazanych decyzją, gdyż zbył nieruchomość, której dotyczy przedmiot postępowania, podstawowym kryterium wyboru spośród trzech wymienionych w art. 52 Prawa budowlanego podmiotów jest posiadanie tytułu prawnego umożliwiającego wykonanie decyzji ${ }^{17}$. W przypadku utraty przez inwestora prawa do dysponowania obiektem i nieruchomością na cele budowlane nałożenie na niego obowiązku doprowadzenia tego obiektu budowlanego do stanu zgodnego z prawem mogłoby okazać się niewykonalne. Inwestor nie miałby bowiem żadnych własnych praw do zabudowanej nieruchomości, a właściciel nie byłby związany tą decyzją. $Z$ tego względu skierowanie $w$ takiej sytuacji decyzji do właściciela nie wydaje się naruszeniem art. 52 Prawa budowlanego. Obowiązek doprowadzenia budynku do stanu zgodnego z prawem nie wypływa $\mathrm{z}$ faktu, że był on stroną postępowania zakończonego pozwoleniem na budowę ani $z$ tego, że obowiązki wynikające $z$ tej decyzji zostały na niego przeniesione, lecz dlatego, że jest on właścicielem

15 Wyrok NSA z dnia 27 marca 2007 r., II OSK 522/06, LEX nr 339391; wyrok NSA z dnia 6 marca 2008 r., II OSK 158/07, LEX nr 468723.

16 J. Dziedzic-Bukowska, J. Jaworski, P. Sosnowski, Leksykon prawa budowlanego, planowania przestrzennego, gospodarki nieruchomościami, Warszawa 2016, s. 58.

17 Z. Kostka, Prawo budowlane. Komentarz, Gdańsk 2004, s. 150; wyrok NSA z dnia 6 marca 2008 r., II OSK 158/07, LEX nr 468723. 
budynku nabytego z określoną wadą prawną. Jeśli budynek wzniesiono niezgodnie z decyzją o pozwoleniu na budowę, to na właścicielu spoczywają wszelkie obowiązki związane $\mathrm{z}$ zalegalizowaniem stwierdzonych odstępstw od zatwierdzonego projektu budowlanego ${ }^{18}$. Przyjęcie poglądu, że adresatem decyzji nakazującej rozbiórkę obiektu budowlanego może być wyłącznie inwestor, prowadziłoby do sytuacji, w których legalizacja samowoli budowlanej lub nakazanie rozbiórki samowolnie wybudowanego obiektu budowlanego w przypadku zbycia tego obiektu przez inwestora innej osobie okazałyby się niemożliwe ${ }^{19}$. Jeżeli zatem inwestor po dokonaniu istotnych odstępstw od zatwierdzonego projektu budowlanego i warunków ostatecznej decyzji o pozwoleniu na budowę utraci uprawnienie do wykonania decyzji nakazującej doprowadzenie wykonanych robót do stanu zgodnego z prawem, to zgodne $\mathrm{z}$ ustawową kolejnością określania podmiotów zobowiązanych do usuwania skutków naruszeń prawa budowlanego właściwe organy mają obowiązek obciążenia obowiązkiem wykonania owego nakazu aktualnego właściciela nieruchomości, na której posadowiony jest obiekt budowlany, w stosunku do którego wydano decyzję o pozwoleniu na wykonanie robót budowlanych ${ }^{20}$.

Mając na uwadze powyższe, należy z całą stanowczością stwierdzić, że w pierwszej kolejności obowiązkiem sporządzenia i przedstawienia projektu budowlanego zamiennego będzie obciążany inwestor posiadający tytuł prawny do obiektu, dopiero na drugim miejscu znajduje się właściciel, a następnie osoba sprawująca trwały zarząd ${ }^{21}$. Jeśli inwestor utraci prawo do dysponowania nieruchomością, wówczas wszelkie obowiązki związane z rozpoczętymi pracami budowlanymi przejmuje jej właściciel. Wskazanie tego ostatniego jako adresata decyzji wynika z faktu, że prawo własności daje najszersze władztwo nad rzeczą. Dlatego obowiązki związane z użytkowaniem obiektu budowlanego będą ciążyć na właścicielu i skutkować domniemaniem na jego rzecz w sytuacjach wątpliwych ${ }^{22}$. W świetle prawa

18 Wyrok NSA z dnia 15 maja 2012 r., II OSK 338/11, LEX nr 1219135.

19 Wyrok NSA z dnia 4 lutego 2011 r., II OSK 247/10, LEX nr 1071219.

20 A. Gliniecki, Komentarz do art. 36, w: Prawo budowlane. Komentarz, red. A. Gliniecki, Warszawa 2016, s. 746; wyrok NSA z dnia 26 marca 2018 r., II OSK 2446/17, LEX nr 2495234.

21 Wyrok NSA z dnia 27 marca 2007 r., II OSK 522/06, LEX nr 339391.

22 W kwestii ustalenia odpowiedniego adresata w stosunku do dokonania określonych czynności w obiekcie budowlanym właściwy organ powinien mieć na uwadze, że to przede wszystkim na właścicielu nieruchomości ciąży obowiązek dbałości o to, aby obiekt 
właścicielem obiektu budowlanego jest podmiot prawa cywilnego będący osobą fizyczną, osobą prawną, jednostką organizacyjną niebędącą osobą prawną, której ustawa przyznaje zdolność prawną, tzn. zdolność do bycia podmiotem praw i obowiązków. Właścicielowi obiektu przysługuje względem niego prawo własności. Zgodnie z art. 140 Kodeksu cywilnego (dalej: K.c.) jako podmiot może on w granicach określonych przez ustawy i zasady współżycia społecznego, z wyłączeniem innych osób, korzystać z obiektu budowlanego zgodnie ze społeczno-gospodarczym przeznaczeniem i tym obiektem rozporządzać. Jak $\mathrm{z}$ tego wynika, własność nawiązuje do tradycyjnego określenia uprawnień właściciela, które obejmują: ius possidendi (uprawnienie do posiadania obiektu), ius utendi-fruendi (uprawnienie do korzystania z obiektu), ius abutendi (uprawnienie do zużycia, rozbiórki obiektu), ius disponendi (uprawnienie do rozporządzania obiektem)23. W przypadku gdy obiekt budowlany przysługuje niepodzielnie kilku osobom, obowiązki spoczywają na wszystkich współwłaścicielach. Nie można zatem obciążyć tymi obowiązkami tylko jednego ze współwłaścicieli, nawet gdy będzie ponosił winę za zaistniały stan rzeczy. Istotnym znaczeniem we współwłasności wydaje się ustalenie, w jakim rozmiarze własność służy poszczególnym jej właścicielom, jednakże w tej sytuacji właściwy organ nadzoru budowlanego nie kieruje się wielkością udziałów we współwłasności. Z tego powodu wszelkie decyzje kierowane są do wszystkich współwłaścicieli obiektu budowlanego ${ }^{24}$. Z kolei w sytuacji, gdy na podstawie umowy o zarządzanie zostanie ustanowiony zarządca nieruchomości, to zgodnie z ustawową kolejnością określania podmiotów zobowiązanych do usuwania skutków naruszeń prawa budowlanego właściwe organy mają obowiązek obciążenia go określonymi czynnościami. Pojęcie zarządcy obiektu budowlanego jest niejednoznaczne i posługują się nim liczne akty normatywne. Generalnie przyjmuje się, że w obowiązującym stanie prawnym przez zarządzanie $\mathrm{w}$ rozumieniu art. 61 Prawa budowlanego należy pojmować trwały zarząd $\mathrm{w}$ rozumieniu art. 43-50 ustawy z dnia

budowlany był użytkowany w sposób zgodny z jego przeznaczeniem, niezależnie od tego, czy właściciel sam ten obiekt wykorzystuje, czy oddał go do użytkowania innemu podmiotowi, zob. wyrok WSA w Poznaniu z dnia 23 kwietnia 2008 r., I SA/Po 508/07, LEX nr 505941; wyrok WSA w Warszawie z dnia 1 kwietnia 2011 r., VII SA/Wa 2514/10, LEX nr 1128161.

23 L. Myczkowski, Wtasność budynków i lokali oraz inne prawa rzeczowe w praktyce, Warszawa 2005, s. 11.

24 Wyrok WSA w Gdańsku z dnia 13 stycznia 2011 r., II SA/Gd 733/10, LEX nr 752627; wyrok WSA w Białymstoku z dnia 8 maja 2008 r., II SA/Bk 535/07, LEX nr 510175. 
21 sierpnia 1997 r. o gospodarce nieruchomościami ${ }^{25}$, zarząd wykonywany zgodnie z przepisami art. 184-190 ustawy o gospodarce nieruchomościami oraz zarząd rzeczą wspólną z punktu widzenia art. 200-201 K.c. ${ }^{26}$ Pojęcie zarządu wskazuje na całokształt czynności prawnych i faktycznych dotyczących przedmiotu. W określeniu „zarządzanie” mieści się także „administracja”, mająca jednak znacznie węższy zakres i obejmująca w zasadzie tylko czynności faktyczne. Czynności w ramach wykonywania zarządu mogą dotyczyć zarówno bieżącej eksploatacji rzeczy, jak i sytuacji szczególnych ${ }^{27}$. Zarządca zatem to podmiot, który troszczy się o utrzymanie nieruchomości w stanie niepogorszonym, a czasami także poprawia stan nieruchomości, odpowiadając za konserwację, naprawy, remonty, utrzymanie czystości i porządku ${ }^{28}$. Jak widać, prawa zarządcy opierają się na konstrukcji upoważnienia do działania w cudzej sferze prawnej, przy czym jego ustanowienie upoważnia go do wykonywania uprawnień i obowiązków w zakresie własności i zarazem wyłącza taką kompetencję właściciela ${ }^{29}$. Zdarza się, że sami właściciele lub współwłaściciele obiektu budowlanego zarządzają swoim obiektem, pełniąc wówczas rolę zarządcy. W tej sytuacji oczywiste staje się, że za podstawę pojawienia się w danym obiekcie jakiegoś zarządcy, który nie jest jego właścicielem, zostaje uznana umowa o zarządzanie zawarta przez tego zarządcę z właścicielem albo ze współwłaścicielami obiektu bądź z reprezentującymi ich innymi osobami. Umowa ta powinna określać zarówno prawa, jak i obowiązki stron, w tym zakres czynności, jakie ma wykonywać zarządca. Świadczy on bowiem usługę na rzecz właściciela lub właścicieli ${ }^{30}$.

Podsumowując komentowane orzeczenie NSA, należy zaznaczyć, że na początku może nam się wydawać, że nałożenie na nowych właścicieli nieruchomości obowiązku doprowadzenia robót do stanu zgodnego z prawem jest niesprawiedliwe. Nakaz przedstawienia zamiennego projektu budowlanego (co jest swoistą sankcją za przekroczenie zakresu pierwotnego projektu budowlanego) został bowiem nałożony nie na sprawcę, który spowodował wykonanie robót budowlanych z odstępstwem od

25 Dz. U. z 2020 r. poz. 1990.

26 Wyrok NSA z dnia 21 marca 2012 r., II OSK 2596/10, LEX nr 1145621.

27 B. Baran, Prawo cywilne dla zarządców nieruchomości, Warszawa 2012, s. 101.

28 E. Bończak-Kucharczyk, Zarządzanie nieruchomościami mieszkalnymi. Aspekty prawne i organizacyjne, Warszawa 2011, s. 22.

29 Wyrok NSA z dnia 3 lutego 2011 r., II OSK 245/10, LEX nr 992523.

30 E. Bończak-Kucharczyk, Zarządzanie nieruchomościami..., s. 23. 
projektu, tj. na inwestorów, lecz na współwłaścicieli nieruchomości. Jednakże niniejszy wyrok NSA w komentowanej sprawie odpowiada przepisom prawa. W cytowanym przez sądy administracyjne i organy administracji publicznej art. 52 Prawa budowlanego wymienia się w określonej kolejności podmioty, które należy obciążyć obowiązkiem przedstawienia projektu zamiennego. W pierwszej kolejności obowiązek ten należy nałożyć na inwestora. Takie stanowisko w omawianym wyroku NSA wpisuje się w ustabilizowaną linię orzeczniczą sądów administracyjnych, co zarazem stanowi wyraz pragmatycznego podejścia do kwestii ustalenia kręgu podmiotów, na które nakłada się obowiązki z zakresu prawa budowlanego. Słusznie uznano, że skoro inwestorzy obecnie nie dysponują tytułem prawnym do nieruchomości (ponieważ uprzednio ją sprzedali), to nie można realnie oczekiwać, że będą w stanie wykonać obowiązki, które sprowadzają się do przeprowadzenia określonych czynności lub robót budowlanych w celu doprowadzenia wykonanych robót budowlanych do stanu zgodnego z prawem. Ponadto glosowany wyrok skłania do innej refleksji. Okazuje się, że nabycie nieruchomości może wiązać się z pewnym ryzykiem prawnym, dlatego w świetle przedstawionego stanu faktycznego i prawnego sprawy w niniejszym orzeczeniu trzeba $\mathrm{z}$ całą mocą podkreślić, jak istotne wydaje się przeprowadzenie badania audytowego przed nabyciem nieruchomości w celu ustalenia, czy została ona zabudowana zgodnie $\mathrm{z}$ prawem. W wielu przypadkach pozwala to na zidentyfikowanie określonego ryzyka prawnego, a tym samym umożliwia znalezienie właściwego rozwiązania jeszcze przed nabyciem nieruchomości.

\section{Bibliografia}

\section{Źródła}

\section{Akty prawne}

Ustawa z dnia 7 lipca 1994 r. - Prawo budowlane, Dz. U. z 2020 r. poz. 1333.

Ustawa z dnia 21 sierpnia 1997 r. o gospodarce nieruchomościami, Dz. U. z 2020 r. poz. 1990.

\section{Orzecznictwo}

Wyrok NSA z dnia 20 marca 2001 r., SA/Bk 1521/00, LEX nr 657438.

Wyrok NSA z dnia 8 grudnia 2006 r., II OSK 44/06, LEX nr 507162. 
Wyrok NSA z dnia 27 marca 2007 r., II OSK 522/06, LEX nr 339391.

Wyrok NSA z dnia 6 marca 2008 r., II OSK 158/07, LEX nr 468723.

Wyrok NSA z dnia 3 lutego 2011 r., II OSK 245/10, LEX nr 992523.

Wyrok NSA z dnia 4 lutego 2011 r., II OSK 247/10, LEX nr 1071219.

Wyrok NSA z dnia 21 marca 2012 r., II OSK 2596/10, LEX nr 1145621.

Wyrok NSA z dnia 15 maja 2012 r., II OSK 338/11, LEX nr 1219135.

Wyrok NSA z dnia 26 marca 2018 r., II OSK 2446/17, LEX nr 2495234.

Wyrok NSA z dnia 20 grudnia 2018 r., II OSK 249/17, LEX nr 2616392.

Wyrok WSA w Poznaniu z dnia 23 kwietnia 2008 r., I SA/Po 508/07, LEX nr 505941.

Wyrok WSA w Białymstoku z dnia 8 maja 2008 r., II SA/Bk 535/07, LEX nr 510175.

Wyrok WSA w Gdańsku z dnia 13 stycznia 2011 r., II SA/Gd 733/10, LEX nr 752627.

Wyrok WSA w Warszawie z dnia 1 kwietnia 2011 r., VII SA/Wa 2514/10, LEX nr 1128161.

Wyrok WSA w Warszawie z dnia 12 maja 2011 r., VII SA/Wa 2071/10, LEX nr 1133266.

Wyrok WSA w Gliwicach z dnia 8 maja 2014 r., II SA/G1 1883/13, LEX nr 1465352.

\section{Literatura}

Babiel T.B., Nadzór budowlany. Kompetencje organów administracji. Wzory. Akty prawne, Warszawa 2001.

Baran B., Prawo cywilne dla zarządców nieruchomości, Warszawa 2012.

Bernatowicz Ł., Nosiński M., Prawo budowlane od dnia 28 czerwca 2015 r. Szczegółowy komentarz do zmian, Gdańsk 2015.

Bielecki M., Proces inwestycyjno-budowlany - aspekty prawne, Warszawa 2016.

Bończak-Kucharczyk E., Zarządzanie nieruchomościami mieszkalnymi. Aspekty prawne i organizacyjne, Warszawa 2011.

Cieślik Z., Komentarz do zmiany art. 36(a) ustawy - Prawo budowlane wprowadzonej przez Dz. U. z 2003 r. Nr 80 poz. 718, 2003 [wyd. el. LEX].

Dessoulavy-Śliwiński J., Komentarz do art. 36a pr. bud., w: Prawo budowlane. Komentarz, red. Z. Niewiadomski, Warszawa 2018.

Dziedzic-Bukowska J., Jaworski J., Sosnowski P., Leksykon prawa budowlanego, planowania przestrzennego, gospodarki nieruchomościami, Warszawa 2016.

Fronczak A., Postepowanie w sprawie istotnego odstapienia od zatwierdzonego projektu budowlanego lub innych warunków pozwolenia na budowę, Kwartalnik Prawa Publicznego 2013, t. 13, nr 3.

Gliniecki A., Komentarz do art. 36, w: Prawo budowlane. Komentarz, red. A. Gliniecki, Warszawa 2016.

Jaśkowska M., Wróbel A., Kodeks postępowania administracyjnego. Komentarz, Kraków 2000. 
Kosicki A., Komentarz do art. 36a pr. bud., w: Prawo budowlane. Komentarz, red. A. Plucińska-Filipowicz, M. Wierzbowski, 2015 [wyd. el. LEX].

Kostka Z., Prawo budowlane. Komentarz, Gdańsk 2005.

Leoński Z., Szewczyk M., Podstawowe instytucje planowania przestrzennego i prawa budowlanego, Poznań 1997.

Myczkowski L., Własność budynków i lokali oraz inne prawa rzeczowe w praktyce, Warszawa 2005.

Radziszewski E., Prawo budowlane. Przepisy i komentarz, Warszawa 2005.

\section{Streszczenie}

Glosa do wyroku NSA z dnia 20 grudnia 2018 r. (II OSK 249/17) dotyczy kwestii ustalenia właściwego podmiotu zobligowanego do sporządzenia i przedstawienia projektu budowlanego zamiennego w celu doprowadzenia robót do stanu zgodnego z prawem. Zdaniem NSA właściwe organy administracji publicznej mają obowiązek obciążenia obowiązkiem wykonania określonych czynności tylko w stosunku do aktualnego właściciela nieruchomości, posiadającego tytuł prawny do dysponowania nieruchomością, na której posadowiony jest obiekt budowlany.

Słowa kluczowe: odstępstwo od zatwierdzonego projektu budowlanego, obiekt budowlany, właściciel nieruchomości, inwestor

\section{GLOSS TO THE JUDGMENT OF THE SUPREME ADMINISTRATIVE COURT OF 20 DECEMBER 2018, II OSK 249/17, LEX 2616392}

\section{Sum mary}

The gloss to the judgment of the Supreme Administrative Court of 20 December 2018 (II OSK 249/17) concerns the issue of determining the appropriate entity obliged to draft and submit a replacement construction project in order to conform the works to compliance with the state compatible law. In opinion of the Supreme Administrative Court, the competent public administration organs are obliged to impose the obligation to perform the specific actions only in relation to the current owner of the property who has the legal title to dispose of the property on which the building is located.

Key words: deviation from the approved construction project, building object, property owner, investor 


\section{КОММЕНТАРИЙ К РЕШЕНИЮ ГЛАВНОГО АДМИНИСТРАТИВНОГО СУДА ОТ 20 ДЕКАБРЯ 2018 Г., II ОSК 249/17, LEX № 2616392 \\ Резюме}

Комментарий к решению Главного Административного Суда от 20 декабря 2018 года (II ОСК 249/17) касается вопроса определения соответствующего субъекта, обязанного составить и представить проект замены, с целью приведения работ в состояние соответствующее закону. Согласно решениям Главного Административного Суда, уполномоченные органы публичного управления обязаны возлагать исполнение обязательства совершать конкретные действия только в отношении нынешнего владельца недвижимости, который имеет законное право распоряжаться недвижимостью, на которой расположен строительный объект.

Ключевые слова: отклонение от утвержденного строительного проекта, строительный объект, владелец недвижимости, инвестор 